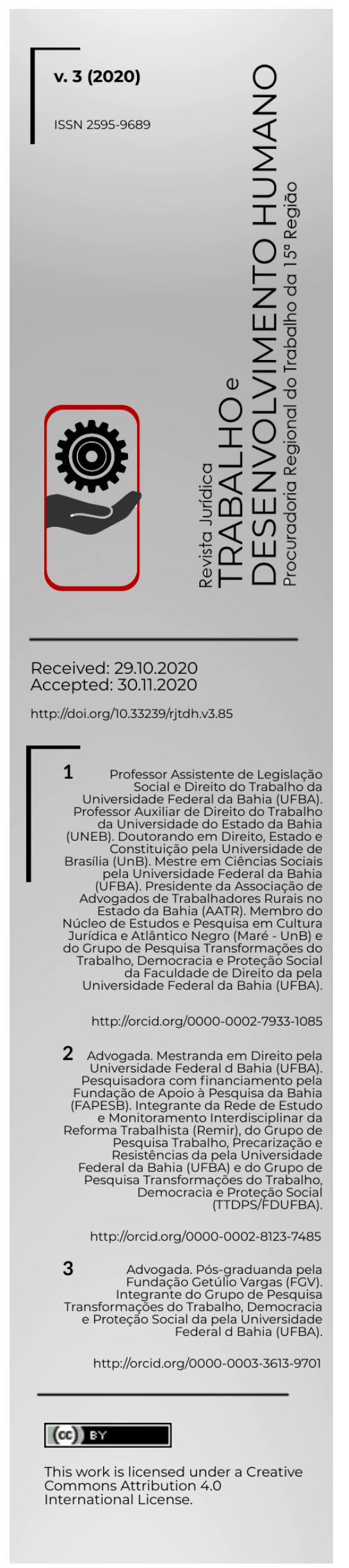

\title{
\#BrequeDosApps e a organização coletiva dos entregadores por aplicativo no Brasil
}

\#BrequeDosApps and the collective organization of delivery app workers in Brazil

\#BrequeDosApps y la organización colectiva de los trabajadores por aplicaciones de entrega en Brasil

Felipe Santos Estrela de Carvalho' Súllivan dos Santos Pereira ${ }^{2}$ Gabriela Sepúlveda Sobrinho ${ }^{3}$

\section{RESUMO}

No presente artigo buscamos analisar o movimento recente de organização coletiva dos entregadores por aplicativo no Brasil na luta por melhores condições de trabalho e vida como alternativa aos vetores precarizantes impostos pela dinâmica atual do capitalismo 4.0 com o uso crescente das tecnologias de informação e comunicação (TICS) nos processos produtivos globais. $O$ texto encontra-se organizado em três sessões, além da introdução e considerações finais. Partindo do resgate histórico das memórias de luta da categoria que remetem à greve dos ganhadores de 1857 na Bahia, procuramos identificar as continuidades e rupturas que marcam o padrão limitado e excludente de regulação do trabalho no país para melhor compreender os desafios à garantia de direitos trabalhistas aos entregadores por aplicativo na contemporaneidade. Em seguida, passamos a investigar as estratégias, discursos e práticas adotadas pelas empresas-aplicativo para negar o reconhecimento do vínculo de emprego aos entregadores, reforçando uma zona de não aplicação dos preceitos constitucionais e infraconstitucionais de proteção social do trabalho aos entregadores. Por fim, destacamos o processo de auto-organização coletiva dos entregadores por aplicativo através da reconstrução crítica da cronologia dos processos de lutas e paralisações realizadas recentemente pelos trabalhadores e que ficaram nacionalmente conhecidas como o \#BrequedosApps.

PALAVRAS-CHAVES: Precarização do trabalho. Entregadores por aplicativos. Organização coletiva. \#Brequedosapps.

\section{ABSTRACT}

In this article we seek to analyze the recent movement of collective organization of delivery application drivers in Brazil in the struggle for better working and living conditions as an alternative to the precarious vectors imposed by the current dynamics of capitalism 4.0 with the increasing use of information and communication technologies (ICTs) in global production processes. The article is organized in three sections, in addition to the introduction and final considerations. Starting from the historical rescue of the fighting memories of the category that refer to the strike of the "ganhadores" of 1857 in Bahia, we seek to identify the continuities and ruptures that mark the limited and exclusive pattern of labor regulation in the country to better understand the challenges to guaranteeing labor rights to deliverers by application in contemporary times. Then, we started to investigate the strategies, speeches and practices adopted by the delivery application companies to deny the recognition of the employment bond to the drivers, reinforcing an area of non-application of the constitutional and infraconstitutional precepts of social protection of the labor to this group. Finally, we highlight the process of collective self-organization of delivery app workers through the critical reconstruction of the chronology of the processes of struggles and stoppages recently carried out by workers and which have become nationally known as \#BrequedosApps.

KEYWORDS: Labor precarization, Delivery App Workers, Collective Organization. \#Brequedosapps. 
RESUMEN

En este artículo buscamos analizar el movimiento reciente de organización colectiva de trabajadores por aplicaciones de entrega en Brasil en la lucha por mejores condiciones de vida y de trabajo como alternativa a los vectores precarios impuestos por la dinámica actual del capitalismo 4.0 con el uso creciente de las tecnologías de la información y la comunicación (TICS) en los procesos de producción globales. El texto está organizado en tres sesiones, además de la introducción y consideraciones finales. A partir del rescate histórico de las memorias de lucha de la categoría que se refieren al paro de los "ganhadores" de 1857 en Bahía, buscamos identificar como continuidades y rupturas que marcan el límite limitado y exclusivo de la regulación laboral en el país para comprender mejor los desafíos para garantizar los derechos laborales a los repartidores por aplicación en la época contemporánea. Luego, comenzamos a investigar las estrategias, discursos y prácticas adoptadas por las empresas de aplicación para negar el reconocimiento del vínculo laboral a los trabajadores de entrega, reforzando un área de no aplicación de los preceptos constitucionales e infra constitucionales de protección social del trabajo a los mensajeros. Finalmente, destacamos el proceso de autoorganización colectiva de los trabajadores de entrega por aplicación a través de la reconstrucción crítica de la cronología de los procesos de luchas y paros llevados a cabo recientemente por los trabajadores y conocidos a nivel nacional como \#BrequedosApps.

PALABRAS CLAVE: Precarización laboral. Trabajadores por aplicaciones de entrega. Organización Colectiva. \#Brequedosapps.

\section{INTRODUÇÃO}

"Nossa vida vale mais que o lucro deles" ${ }^{1}$. Com essas palavras de ordem, os trabalhadores de entrega por aplicativo, em sua maioria, jovens negros, moradores das periferias das grandes cidades brasileiras, num exercício de auto-organização coletiva, em meio a maior pandemia global do século XXI, conseguiram realizar, em julho de 2020, duas grandes paralisações nacionais que ficaram conhecidas nas redes sociais como o \#BrequedosApps².

No dia 1 을 de julho, entregadores por aplicativos como Rappi, iFood, Uber Eats, Loggi, Glovo e James paralisaram carros, motos e bicicletas em ao menos 13 estados e no Distrito Federal. Cidades como São Paulo, Belo Horizonte, Brasília, Fortaleza e Salvador registraram grandes manifestações de rua denunciando a exploração desmedida da categoria ${ }^{3}$. Na pauta reivindicatória, constava: o aumento do valor da hora de trabalho (expressa no aumento da

\footnotetext{
${ }^{1}$ BREQUE dos Apps: nossas vidas valem mais do que o lucro deles. Esquerda Diário, São Paulo, 02 de jul. de 2020. Disponível em: https://www.esquerdadiario.com.br/Breque-dos-Apps-nossas-vidas-valem-mais-que-o-lucrodeles. Acesso em: 22 set. 2020.

2 BRAGA, Ruy; SANTANA, Marco Aurélio. \#BrequedosApps: enfrentando o uberismo. Boitempo, 25 de jul. de 2020. Disponível em: https://blogdaboitempo.com.br/2020/07/25/brequedosapps-enfrentando-o-uberismo/. Acesso em: 22 set. 2020.

${ }^{3}$ RIBEIRO, Gabriel Francisco. Greve não para apps, mas mostra força de entregadores, nova data é votada. UOL, São Paulo, 01 de jul. de 2020. Disponível em: https://www.uol.com.br/tilt/noticias/redacao/2020/07/01/grevenao-para-apps-mas-afeta-sistema-e-mostra-forca-de-entregadores.htm. Acesso em: 22 set. 2020.
} 
taxa paga por quilômetro rodado); o aumento do valor mínimo por corrida; o fim dos bloqueios unilaterais; oferecimento de equipamentos de proteção individual por conta da pandemia da Covid-19; bem como mudanças no sistema de pontuação de algumas empresas.

Percebido como o movimento trabalhista mais importante desde o início do ciclo grevista iniciado com as greves dos trabalhadores das hidroelétricas de Santo Antônio e Jirau, em Rondônia e Belo Monte no Pará, realizadas em 2011 e 2012 4 , até a greve geral de 28 de abril de 2017 com mais de 40 milhões de trabalhadores paralisados ${ }^{5}$, as mobilizações dos chamados trabalhadores das plataformas digitais têm colocado, novamente, o instrumento político da greve no centro das estratégias de luta por direitos no país.

Segundo dados do Instituto Locomotiva ${ }^{6}$, cerca de 17 milhões de pessoas usam algum aplicativo regularmente para obtenção de renda, incluindo aí trabalhadores autônomos, profissionais liberais e empregados que buscam as plataformas para complementar os salários. Os dados revelam ainda que os aplicativos de entrega são hoje o maior "empregador" do país, com 5,5 milhões de profissionais cadastrados, sendo quatro milhões de trabalhadores autônomos e o restante composto por aqueles que têm emprego fixo e buscam as plataformas para ampliar a renda própria e familiar.

Entretanto, muito embora as plataformas mobilizem um contingente de força de trabalho superior a qualquer setor da atividade econômica no país, perfazendo lucros extraordinários, as empresas da chamada economia de compartilhamento não se consideram empregadoras desses trabalhadores. Ao se eximir das responsabilidades correlatas ao (não) reconhecimento dos vínculos empregatícios, as plataformas digitais deixam esses trabalhadores à própria sorte, arcando desproporcionalmente com os custos e riscos da atividade econômica, afastando a incidência das normas de proteção social trabalhista.

\footnotetext{
${ }^{4}$ CAMPOS, Cauê. Conflitos trabalhistas nas obras do PAC: o caso das Usinas Hidrelétricas de Jirau, Santo Antônio e Belo Monte. Campinas, SP: Dissertação, 2016.

${ }^{5}$ BRASIL. Paim diz que greve atingiu 40 milhões de trabalhadores e foi a maior da história do país. In: Agência Senado. Brasília: Senado Federal, 2017.

${ }^{6}$ GRAVAS, Douglas. Aplicativos como Uber e iFood são fonte de renda de quase 4 milhões de autônomos. 0 Estado de São Paulo, 2020. Disponível em: https://www.ilocomotiva.com.br/singlepost/2019/04/29/ESTAD\%C3\%830-Na-crise-aplicativos-como-Uber-e-iFood-viram-maior-empregador-dopa\%C3\%ADs. Acesso em: 24 set. 2020.
} 
Revista Jurídica Trabalho e Desenvolvimento Humano

Procuradoria Regional do Trabalho da 15a Região

A batalha dos entregadores por aplicativo pela instituição de direitos trabalhistas mínimos rememora um padrão de regulação do trabalho no Brasil marcado pela morosidade seletiva e pela baixa cobertura e efetividade dos seus institutos de proteção social. Foi assim com o projeto vagaroso e controlado de abolição formal da escravidão, com a exclusão de trabalhadoras domésticas e trabalhadores rurais da proteção social celetista ${ }^{7}$ e está sendo assim com os atuais trabalhadores de plataforma digitais ${ }^{8}$. Mais do que estabelecer diferenças a partir do modo de subsunção do trabalho entre essas categorias, o importante é perceber o Direito do Trabalho como um projeto de proteção social limitado, desde sua origem, a categorias específicas de trabalhadores, fixando uma zona de exceção trabalhista permanente para trabalhadores em funções de baixa qualificação e remuneração, particularmente negras e negros. É neste cruzamento marcado pela exclusão que domésticas, trabalhadores rurais e entregadores de aplicativo se encontram.

A crise do regime de acumulação tayloriano-fordista, manifestada em sua dimensão estrutural a partir da década de 1970 desencadeou um vasto processo de reestruturação produtiva que resultou nas formas de acumulação flexível experimentada na atualidade ${ }^{9}$. Mais recentemente, como desdobramento da crise financeira do ano de 2008 , esse conjunto de transformações vivenciado no mundo do trabalho se potencializou, observando o mesmo vetor precarizante, com o que Ricardo Antunes denomina de ascensão da ciberindustria ou indústria $4.0^{10}$.

Com premissas que objetivam acabar com o coletivismo consequente das políticas redistributivas, assistenciais, planificadoras, reguladoras e protecionistas que vinham se desenvolvendo nesse período, as políticas neoliberais rechaçam qualquer tipo de ação tendente a interferir nos interesses privados ${ }^{11}$. Os novos processos de austeridade neoliberal aprofundam o desmantelamento do Estado Social por meio do movimento triplo de

\footnotetext{
7 ALVES, Raissa Roussenq. Entre o silêncio e a negação: trabalho escravo contemporâneo sob a ótica da população negra. Belo Horizonte: Letramento, 2019.

${ }^{8}$ ANTUNES, Ricardo; FILGUEIRAS, Vitor. Plataformas, digitais, uberização do trabalho e regulação no capitalismo contemporâneo. Bazilian Journal of Communication, PPGCOM-UFF. v. 39, n. 1, 2020.

${ }_{9}^{9}$ ANTUNES, Ricardo. Qual é o Futuro do Trabalho na era digital?. Revista Laborare, ano III, no 4, jan-jun/2020.

${ }^{10}$ ANTUNES, Ricardo. O privilégio da servidão. São Paulo: Boitempo, 2018.

11 DARDOT, Pierre; LAVAL, Christian. A nova razão do mundo: ensaio sobre a sociedade neoliberal. São Paulo: Boitempo, 2016.
} 
Revista Jurídica Trabalho e Desenvolvimento Humano

Procuradoria Regional do Trabalho da 15a Região

privatização dos bens e serviços públicos, de individualização dos riscos sociais e de mercantilização total da vida ${ }^{12}$.

Nessa empreitada, um dos desafios que nos mobiliza é contextualizar como o processo de organização coletiva está ocorrendo nesse momento de disseminação da racionalidade algorítmica nos processos produtivos da chamada indústria 4.0 e como isso tem impulsionado os novos processos de precarização social do trabalho. Sobretudo, pela adoção de estratégias de gestão da produção e da força de trabalho voltadas para o ocultamento das relações de assalariamento, da condição de trabalhador, e por consequência, da própria condição de sujeito de direito desses trabalhadores de plataformas digitais ${ }^{13}$.

Objetivando atingir os fins acima propostos, inicialmente, será feito um relato dos movimentos de auto-organização coletiva dos entregadores de aplicativo enquanto categoria, associando o processo vivido na atualidade com a greve negra de 1857 na Bahia, relatada pelo historiador João José Reis, em seu livro "Ganhadores"14. Para tanto, será destacada as correlações possíveis a partir das rupturas e continuidades históricas identificadas entre os fenômenos. Posteriormente, será realizada uma análise sobre as estratégias, discursos e práticas adotadas pelas empresas-aplicativo para negar jurídica e idelogicamente o reconhecimento do vínculo de emprego aos entregadores, reforçando uma zona de não aplicação dos preceitos constitucionais e infraconstitucionais de proteção social do trabalho aos entregadores. Por fim, analisar-se-á o processo de auto-organização coletiva dos entregadores por aplicativo através da reconstrução crítica da cronologia dos processos de lutas e paralisações realizadas recentemente pelos trabalhadores e que ficaram nacionalmente conhecidas como o \#BrequedosApss.

Considerando esta nova conjuntura do mundo do trabalho, esse artigo pretende contribuir com novas premissas que possam auxiliar na resistência do campo juslaboral ao fenômeno que tem importado, em grande medida, na negação de direitos aos trabalhadores e acirramento da precarização do trabalho.

\footnotetext{
12 FERREIRA, António Casimiro. A sociedade da austeridade: poder, medo e direito do trabalho de exceção. In: Revista Crítica de Ciências Sociais. Online, 95, 2011.

${ }^{13}$ ABÍLIO, Ludmila. Uberização do trabalho: Uberização: do empreendedorismo para o autogerenciamento subordinado. Revista Psicoperspectivas: Individuo y sociedad. Vol. 18, n. 3, p.1-11, 2019.

${ }^{14}$ REIS, João José. Ganhadores: a greve negra de 1857 na Bahia. São Paulo: Companhia das Letras, 2019.
} 
Revista Jurídica Trabalho e Desenvolvimento Humano

Procuradoria Regional do Trabalho da 15a Região

\section{Entregadores: genealogia da exploração e resistências}

A luta dos entregadores por aplicativo contra a exploração expressa os dilemas históricoestruturais de um mercado de trabalho nacional marcado por profundas desigualdades raciais, de classe, gênero e geração que rementem genealogicamente às experiências da diáspora africana e da escravidão moderna. Ao mesmo tempo em que encerra novos desafios para o campo da regulação trabalhista, provocados pela crescente incorporação das tecnologias da informação e comunicação nos processos produtivos.

É possível estabelecer aproximações analíticas entre o processo de constituição e organização dos entregadores de aplicativo com a luta dos ganhadores ${ }^{15}$ no contexto do préabolição. As últimas décadas do século XIX foram marcadas pela crescente conflituosidade urbana $^{16}$ com manifestações abolicionistas, efervescente atuação de escravizados e tímidas manifestações de trabalhadores livres ${ }^{17}$. A América, ainda escravista, vivia o fantasma do haitianismo ${ }^{18}$, portanto, o medo das elites brancas de que a população negra empreendesse um movimento de revolta e vingança social serviu de base para a elaboração de políticas institucionais de contenção dessa força de trabalho, do pré ao pós-abolição.

O censo de 1872 já apontava a ampla força demográfica, populacional de pretos, pardos, crioulos e africanos livre, repercutindo por sua vez na composição racial da força de trabalho nacional. O cenário de avanço da urbanização especialmente com a ampliação dos setores de

\footnotetext{
${ }^{15}$ Os ganhadores eram uma categoria composta por homens escravizados ou não (libertos ou forros), em sua grande maioria negros, que trabalhavam, sobretudo, com a circulação de objetos e pessoas, por meio de saveiros, alvarengas, canoas e cadeiras de arruar, eram responsáveis pelo saneamento básico da cidade e por alguns outros serviços, como: mecânico, pedreiro, ferreiro, alfaiate, sapateiro, etc. Já as ganhadeiras, eram as mulheres, em sua maioria escravizadas, que mercadejavam como ambulantes, geralmente fazendo a ponte entre o comércio da Cidade Baixa e os clientes na Cidade Alta que estavam dispostos a pagar mais caro pela comodidade da entrega domiciliar dos produtos, elas vendia de tudo um pouco, alimentos, tecidos, objetos importados, entre outros. Muitos desses escravizados e escravizadas tinham dupla jornada, trabalhavam na atividade doméstica e posteriormente trabalhava nas ruas (REIS, João José. Ganhadores: a greve negra de 1857 na Bahia. São Paulo: Companhia das Letras, 2019).

${ }^{16}$ FREYRE, Gilberto. Sobrados e Mocambos. 3 ed. Rio de Janeiro: José Olympio, 1961; KOWARICK, Lúcio. Trabalho e vadiagem: A origem do trabalho livre no Brasil. 2 ed. Rio de Janeiro: Paz e Terra, 1994; CHALHOUB, Sidney. Cidade febril: cortiços e epidemias na Corte imperial. São Paulo: Companhia das Letras, 1996.

${ }^{17}$ CHALHOUB, Sidney. Trabalho, lar e botequim: o cotidiano dos trabalhadores no Rio de Janeiro da Belle Époque. São Paulo: Brasiliense, 1986.

${ }^{18}$ QUEIROZ, Marcus. Constitucionalismo e Atlântico Negro. 2 ed. São Paulo: Lumen Juris, 2018.
} 
Revista Jurídica Trabalho e Desenvolvimento Humano

Procuradoria Regional do Trabalho da 15a Região

serviços, como transporte, abastecimento, carga e descarga, contou amplamente com a participação da população negra escrava, livre e liberta ${ }^{19}$.

O controle geocorpóreo do trabalho negro foi acentuando-se com o avanço da urbanização, especialmente após as rebeliões escravas ocorridas nas primeiras décadas do século XIX, a exemplo da Revolta dos Malês ${ }^{20}$ que contou com uma ampla rede de colaboração urbana, especialmente das mulheres escravizadas, livres e libertas que mercadejavam alimentos nas ruas da Cidade de Salvador. Era preciso taxar, disciplinar, monitorar e conter os africanos que circulavam dinamicamente na cidade com a expansão do sistema de ganho no contexto do escravismo urbano.

A greve negra de 1857, feitas pelos ganhadores, na antiga Cidade da Bahia, foi um grande e inédito protesto contra a medida provincial opressora que disciplinava sobre o controle dos corpos, da "liberdade" de locomoção, da organização do trabalho e ainda onerava por meio de encargos tributários a atividade laboral do ganho. A postura municipal exigia o registro desses trabalhadores através de matrículas e o uso de uma chapa de metal no pescoço para identificar os ganhadores no exercício das suas funções. Além da oneração excessiva para realização do seu labor cotidiano, os ganhadores receberam as novas regras como medidas que acirravam a estigmatização do seu trabalho. Conforme aponta João Reis, a greve negra foi um ousado movimento de insurreição e desobediência civil à intensa campanha institucional de discriminação étnica que sujeitava os africanos escravizados, libertos e livres a um grande controle governamental.

Durante uma semana inteira, trabalhadores negros cativos e libertos que dinamizavam a vida urbana da Salvador oitocentista, uma das cidades portuárias mais movimentadas do Atlântico Sul decidiram paralisar os serviços de entrega de mercadorias, abastecimento de água e transporte de pessoas para denunciar a exploração sem limites impostas pela administração imperial. Carregadores de pau e corda, cesto e tina, carregadores de cadeiras de arruar cruzaram os braços e desaparecem dos cantos e freguesias da cidade. A greve

\footnotetext{
${ }^{19}$ CHALHOUB, Sidney. Sujeitos no imaginário acadêmico: escravos e trabalhadores na historiografia brasileira desde os anos 1980. Cad. Ael, v. 14, n. 26, 2009.

${ }^{20}$ REIS, João José. Rebelião escrava no Brasil: a história do levante dos malês em 1835. São Paulo: Companhia das Letras, 2003.
} 
revelou-se uma intensa e articulada resposta às opressões sofridas secularmente, narrada como um "episódio que deixou perplexas as autoridades políticas e policiais da província da Bahia e repercutiu como curiosidade excêntrica nos principais jornais da corte imperial"21. 0 trabalho do ganho, bem como o de entrega por aplicativos (sobretudo, no pós-pandemia da Covid-19), em um primeiro momento remetem às figuras do biscate e do freelancer, devido ao caráter fragmentário e irregular da prestação do serviço. Contudo, em uma análise mais detida, pode-se notar que essas duas figuras desempenham importantes papéis na distribuição/circulação de mercadorias nos centros urbanos, sendo indispensáveis no processo de realização do valor e movimentação das economias nacionais

Em verdade, o sistema de ganho parece persistir de alguma forma na realidade do trabalho contemporâneo brasileiro, especialmente após a implementação da Reforma Trabalhista (Lei $\mathrm{n}$ ⒔469/2017). Assim como no escravismo urbano, onde o cativo se submetia a toda sorte de serviços e comércio ambulante para poder pagar o escravocrata com uma parcela do "ganho" auferido, sobreviver e ainda acumular algum pecúlio para comprar sua alforria, o trabalhador intermitente de hoje não sabe ao certo quando trabalhará e, por consequência, se terá alguma renda ao final do mês. A lógica do trabalho intermitente obriga o trabalhador a estabelecer uma multiplicidade de vínculos para preencher a porosidade da sua jornada e assim promover a subsistência própria e a de sua família ao custo da conversão massiva do seu tempo social em tempo econômico.

Antunes $^{22}$ defende a ideia de que o trabalho intermitente é todo aquele em que o trabalhador é convocado para realizar alguma atividade (predominantemente de serviços) e é remunerado estritamente pelo que fez e nada pelo tempo de tempo a disposição do empregador. Assim como os ganhadores de ontem, os intermitentes e entregadores de aplicativo de hoje lidam com a instabilidade e a insegurança, com o risco da carestia, com a sobrecarga de trabalho e com a depreciação do valor social do seu labor.

Em ambos os contextos esses trabalhadores não eram proprietários dos meios de produção, estavam à margem do trabalho formal e vivenciavam a superexploração do

\footnotetext{
${ }^{21}$ REIS, João José. Ganhadores: a greve negra de 1857 na Bahia. São Paulo: Companhia das Letras, 2019, p. 353. ${ }^{22}$ ANTUNES, Ricardo. Riqueza e miséria do trabalho no Brasil IV: trabalho digital, autogestão e expropriação da vida: o mosaico da exploração. Org. Ricardo Antunes. 1 ed. São Paulo: Boitempo, 2019, p. 16.
} 
Revista Jurídica Trabalho e Desenvolvimento Humano

Procuradoria Regional do Trabalho da 15a Região

trabalho, com mecanismos próprios de gestão da sua mão de obra. Essa divisão socio-racial do trabalho, articulando raça e classe, é a peculiaridade encontrada nas formas de subsunção do trabalho abstrato no contexto do capitalismo dependente brasileiro. Pois, enquanto relação social, o capitalismo utiliza as condições materiais objetivas e subjetivas presentes em determinado contexto histórico e social para ampliar e intensificar a extração do mais-valor.

A existência de ambas as formas de organização do trabalho, cada uma em sua época, pressupõe que o trabalhador não seja reconhecido como sujeito de direito. Se no passado a negação sistemática da humanidade do negro africano serviu para legitimar a exploração escravista, hoje nos deparamos com discursos institucionais que reforçam uma pretensa liberdade, a livre iniciativa, a autonomia negocial e a natureza empreendedora do serviços prestados por meio de aplicativos e plataformas digitais para afastar a incidência do regras protetivas a esses trabalhadores.

A situação de marginalidade do trabalhador negro pode ser percebida em sua dimensão transtemporal, posto que, vem sendo reproduzida continuamente a partir dos imperativos que marcaram o capitalismo brasileiro em suas diversas fases. É importante destacar que as estratégias de acumulação de capital no país têm passado pela superexploração racial, envolvendo um déficit de cobertura social a negras e negros no mercado de trabalho.

No caso do trabalho em aplicativos ou plataformas digitais, Antunes ${ }^{23}$ denomina de "escravidão moderna na era digital", se referindo não só aos entregadores de aplicativos, mas sim a toda forma de contratação que utiliza o trabalho fragmentado que objetiva eliminar o trabalho improdutivo. Obviamente que não se trata de transpor mecanicamente os preceitos da escravidão moderna para a contemporaneidade do trabalho digital, mas destacar as novas e sofisticadas formas de aprisionamento impulsionadas pelo uso massivo das tecnologias da informação e comunicação.

Dessa forma, importa frisar que a maioria dos ganhadores eram escravizados, ou seja, trabalhavam sob o mando de um regime escravista legalizado ${ }^{24}$ pelo governo, não eram

\footnotetext{
${ }^{23}$ ANTUNES, Ricardo. Riqueza e miséria do trabalho no Brasil IV: trabalho digital, autogestão e expropriação da vida: o mosaico da exploração. Org. Ricardo Antunes. 1 ed. São Paulo: Boitempo, 2019, p. 16.

24 Para Luiz Gama, não existe "escravidão jurídica", pois, o direito pressupõe a igualdade abstrata formal, então pressupõe uma igualdade, uma justiça, portanto, se alguém está sendo injustiçado dentro da linguagem do
} 
sequer sujeitos de direito dentro da ordem capitalista mercantil. Esse importante aspecto deve ser visto como uma diferença, sob pena de menosprezo e diminuição do que foi a escravidão colonial. A vitória abolicionista é inegável ${ }^{25}$, atualmente existe uma certa liberdade $^{26}$ e todos são sujeitos de direito ${ }^{27}$, mesmo que exista uma restrição de acesso à cidadania e todas as dificuldades impostas pelas diferenças de gênero, classe e raça.

A despeito das novidades impostas pelo avanço da tecnologia da informação e da gestão algorítmica, os dilemas dos trabalhadores de aplicativos se somam ao de outras categorias, especialmente aquelas compostas majoritariamente por pessoas negras, especialmente nos setores de transporte, abastecimento e distribuição de mercadorias.

\section{A negação do vínculo de emprego na indústria 4.0: estratégias, discursos e práticas}

O direito do trabalho e os trabalhadores, nas últimas duas décadas, têm vivenciado um ciclo crítico, cada vez mais tensionado pela hegemonia neoliberal, sendo continuamente desafiados a capturar e a, quiçá, responder a esse fenômeno de solapamento da sociedade do trabalho. Como fruto do fracasso do liberalismo na sociedade capitalista, o neoliberalismo é uma espécie de resposta ao reformismo social ocasionado pela crise liberal econômica do final do século XIX. A universalização dos pressupostos neoliberais como a privatização das atividades estatais, a desregulamentação econômica, trabalhista e ambiental, a eliminação das reservas de mercado e de qualquer forma de protecionismo, a generalização da concorrência como norma de conduta e da empresa como modelo de subjetividade tem

\footnotetext{
direito, então não é direito (FONSECA, Lígia Ferreira. Luiz Gama por Luiz Gama: carta a Lúcio de Mendonça. Teresa revista de Literatura Brasileira. São Paulo, 2008, p. 300-321).

${ }^{25}$ Conforme Thula Rafaela de Oliveira Pires, esse "movimento abolicionista" é denominado como processo de abolição formal da escravatura (PIRES, Thula Rafaela de Oliveira. Criminalização do Racismo entre política de reconhecimento e meio de legitimação do controle social dos não reconhecidos; orientadora: Gisele Cittadino. 2v. Tese (Doutorado em Direito) - Pontifícia Universidade Católica do Rio de Janeiro, Departamento de Direito, Rio de Janeiro, 2013, p. 102).

${ }^{26}$ Sem o trio "liberdade individual, igualdade formal e propriedade não poderia haver contratos, mercado e, portanto, capitalismo" (ALMEIDA, Silvio Luiz de. O que é racismo estrutural?. Belo Horizonte (MG): Letramento, 2018, p. 145).

${ }^{27}$ Salienta-se que "a relação jurídica entre os sujeitos é apenas outro lado das relações entre os produtos do trabalho tornados mercadoria" (PACHUKANIS, Evguiéni Bronislávovitch. Teoria Geral do Direito e Marxismo. Trad. Paula Vaz de Almeida. São Paulo: Boitempo, 2017, p. 02).
} 
Revista Jurídica Trabalho e Desenvolvimento Humano

Procuradoria Regional do Trabalho da 15a Região

pressionado a desconstituição das garantias e instrumentos de regulação pública das relações de trabalho.

Druck $^{28}$ frisa que o neoliberalismo é a transferência de responsabilidades para o obreiro e provoca um intenso processo de reestruturação da produção e do trabalho que culminou com a dinâmica da precarização social do trabalho. No Brasil, esse processo vem se instalando econômica, social e politicamente com o objetivo de reconfigurar a precarização histórica e estrutural do trabalho já existente, contudo, agora justificada pela necessidade de adaptação aos novos tempos globais ${ }^{29}$.

O capitalismo, contemporaneamente sob a forma da ideologia neoliberal, molda as subjetividades humanas em uma perspectiva individualizante e meritocrática, em que o indivíduo é o único responsável por seu sucesso e por seu fracasso ${ }^{30}$. Como bem afirma Bourdieu, essas condutas neoliberais, tidas como novas, em verdade, constituem uma roupagem camuflada para antigas práticas arcaicas do patronato ${ }^{31}$.

O avanço da tecnologia da informação e da gestão algorítmica ao longo das cadeias globais de valor, o exercício laboral em condições degradantes e sem a devida cobertura social aproxima a luta dos entregadores de aplicativo e demais trabalhadores de plataformas digitais à realidade de amplas parcelas do mercado de trabalho brasileiro. A desregulamentação e o afastamento da condição de empregado dessas categorias representam, na verdade, a manutenção do poder de uma classe patronal legatária dos padrões de exploração forjados ao longo de quase quatro séculos de escravidão colonial.

\footnotetext{
${ }^{28}$ DRUCK, Maria da Graça. Trabalho, precarização e resistências: novos e velhos desafios? Cadernos CRH, Salvador, v. 24, p. 37-57, 2011.

${ }^{29}$ A profunda transformação na organização do trabalho interno, sobretudo a partir de 1990, com a globalização (responsável pelo deslocamento da produção industrial dos países do Norte, para os países subdesenvolvidos do Sul, com menor poder de organização coletiva e uma recente cidadania regulamentada) incentivou uma série de mudanças legislativas (responsáveis por introduzir o contrato a tempo parcial, o contrato por tempo determinado e o trabalho autônomo). E mais recentemente, com a Reforma Trabalhista de 2017, que enfraqueceu o Direito Coletivo do Trabalho, o acesso à justiça, bem como incentivou a pejotização do trabalho e introduziu a precária figura do contrato de trabalho intermitente no ordenamento jurídico pátrio.

${ }^{30}$ GALVÃO, Andréia. A greve e as perspectivas do movimento entregadores. A Terra é Redonda, São Paulo, 14 de jul. de 2020. Disponível em: https://www.eco.unicamp.br/remir/index.php/sindicalismo/189-a-greve-e-asperspectivas-do-movimento-entregadores. Acesso em: 03 dez. 2020.

${ }^{31}$ BOURDIEU, Pierre. Contrafogos: táticas para enfrentar a invasão neoliberal. Tradução Lucy Magalhães. Rio de Janeiro: Jorge Zahar, 1998.
} 
A denominada quarta revolução industrial, ou simplesmente indústria 4.0, caracterizase pelo manejo de redes inteligentes aptas a programar e conectar processos produtivos que envolvem a inteligência artificial, internet das coisas, nanotecnologia e outros recursos que aprofundam os avanços da terceira revolução industrial, de modo acelerado ${ }^{32}$. Essas modificações permitem a informatização dos processos produtivos e, possuem como objetivo, a eliminação de postos clássicos de trabalho, pois é criada uma ideia social de fetiche da máquina. Bem como, cria a falsa ideia social de que o trabalho não é central e sim a máquina. Essa ideologia faz crer que é possível fazer a substituição do homem pelo maquinário, sendo que todo aparato tecnológico é gerido e administrado por pessoas.

Paralelamente à grande expectativa que acompanhou o surgimento e a disseminação das tecnologias da informação e comunicação, sugerindo a participação equânime dos players econômicos, na prática, o que verificamos foi à oligopolização do mercado por meio de um punhado de empresas globais. Bridi e Lima ${ }^{33}$ pontuam que as grandes corporações financeiras (Amazon, Netflix, Apple, Microsoft etc.), as redes sociais digitais (Facebook, Twitter, Tumblr, Instagram etc.), os gerenciadores de busca (Google, Bing etc.) e as plataformas de mobilidade e entrega (Uber, Rappi, Loggi, 99, Cabify etc.) todos elas dispõem atualmente de uma produção contínua e massiva de dados acerca do tipo e da amplitude de nossas interações sociais.

As empresas de plataformas, nas quais os meios de produção basicamente se caracterizam pela capacidade de processamento de dados e informações, são exemplos emblemáticos dessa "revolução" digital 4.0. Esse fenômeno tem forte influência no mundo do trabalho, porque modifica o processo de organização das relações trabalhistas ao implantar uma nova forma de gestão que rompe com o paradigma instituído pela experiência fordista. "Como consequência dessas disrupções na forma de organizar as empresas,

\footnotetext{
32 SCHWAB, Klaus. The fourth industrial Revolution. World Economic Forum: Cologny/Geneva, Switzerland, 2016.

33 BRIDI, Maria Aparecida; LIMA, Jacob Carlos. Trabalho digital e emprego: a reforma trabalhista e o aprofundamento da precariedade. Caderno CRH [online]. 2019, vol. 32, n. 86 [cited 2020-09-24], pp.325342. Disponível

em: http://www.scielo.br/scielo.php?script=sci arttext\&pid=\$010349792019000200325\&lng=en\&nrm=iso. Acesso: em 18 set 2020.
} 
ocorrem, igualmente, transformações e novos arranjos no modo de trabalhar por meio dessas plataformas digitais de trabalho" ${ }^{34}$.

Importa salientar que a implantação dessa reorganização requer a disseminação da antiga estratégia capitalista de utilização do exército de reserva como mecanismo de pressão sobre os setores formais do mercado de trabalho. Ou seja, a sua viabilidade depende das disputas ideológicas que induzem uma suposta necessidade de que o trabalhador se adeque a essa nova realidade, sob o risco de ficar sem sustento. Nesse "novo normal", a retórica da suposta liberdade, do empreendedorismo e da condição de autonomia do prestador de serviços -chamando-os de autônomos (crowdwork) ou não (on-demand) ${ }^{35}$ - é utilizada para negar o acesso aos direitos fundamentais trabalhistas.

Conforme dito nas linhas anteriores, a tentativa de anular a relação de trabalho e, por consequência, camuflar as formas de assalariamento, em verdade, trata-se de uma lógica de mercado que é reiterada e repetida de diversos modos, sendo reproduzida e reinventada em diferentes oportunidades da história do capitalismo, e particularmente no brasileiro: "ganhadores", "trabalhadores avulsos", "diaristas", "pejotização", "trabalhadores intermitentes" e "empreendedores", entre outras formas. Assim, no contexto da chamada indústria 4.0, o fenômeno da "uberização", conforme sinalizado por Cavalcante e Filgueiras ${ }^{36}$, não é o primeiro "adeus à classe trabalhadora", que já teve em diversos momentos e por diversos argumentos sua condição enquanto sujeito de direito e trabalhador retiradas ou ao menos marginalizadas.

Cavalcante e Filgueiras atestam que na produção acadêmica, nas instituições públicas, nos meios de comunicação e na iniciativa privada em geral, há uma polissemia de termos para definir as transformações ocorridas no capitalismo contemporâneo e no mundo do trabalho, que de alguma forma estariam associadas à crescente incorporação das novas tecnologias da informação e comunicação. "Gig-economy, platform economy, sharing

\footnotetext{
${ }^{34}$ OLIVEIRA, Murilo Carvalho Sampaio. Formas de contratação do trabalhador na prestação de serviços sob plataformas. In: CARELLI, Rodrigo de Lacerda; CAVALCANTI, Tiago M.; FONSECA, Vanessa Patriota da. Futuro do Trabalho: os efeitos da revolução digital na sociedade. Brasília: ESMPU, 2020.

${ }^{35}$ CAVALCANTE, Sávio; FILGUEIRAS, Vitor. O trabalho no século XXI e o novo adeus a classe trabalhadora. Revista princípios, no 159, jul.-out., 2020.

${ }^{36}$ CAVALCANTE, Sávio; FILGUEIRAS, Vitor. O trabalho no século XXI e o novo adeus a classe trabalhadora. Revista princípios, no 159, jul.-out., 2020.
} 
economy, crowdsourcing, on-demand economy, uberização, crowdwork, trabalho digital, entre outros, para os quais há mais dissenso do que consenso" 37 .

Observando a realidade brasileira, a uberização do trabalho tem se revelado como o fenômeno mais emblemático, sobretudo, quando consideramos a situação dos motoristas e entregadores de aplicativo que tem como principais instrumentos de trabalho, os seus veículos (sejam pessoais, emprestados ou alugados e as despesas provenientes deste, como seguro, manutenção e combustível é de inteira responsabilidade do trabalhador) e smartphones.

Abílio ${ }^{38}$ entende que a uberização se refere a um novo estágio da exploração global do trabalho que implicou em mudanças qualitativas tanto no estatuto do trabalhador, na configuração das empresas, bem como nas formas de controle, gerenciamento e expropriação do trabalho. Trata-se de um novo estágio nas estratégias de externalização dos riscos e obrigações trabalhistas que retira as garantias sociais trabalhistas, na medida em que a subordinação se reestrutura por meio de mecanismos mais precarizantes e benéficos ao capital.

Os trabalhadores por aplicativos são supostamente contratados pela via digital para a prestação de serviço presencial, através da entrega de mercadorias ao consumidor final. A plataforma, seja ela Uber, Rappi, Ifood, Glovo, entre outras, colocam-se como um meio de conexão entre o entregador e o consumidor final, como se essa fosse a sua atividade finalística e o aplicativo ou algoritmo como um mero "intermediador". Inclusive, ao ser questionada judicialmente a Uber - empresa de motoristas por aplicativo que também fornece o serviço de entrega de alimentos e demais mercadorias - afirmou que é uma plataforma voltada para os motoristas, aduzindo que apenas colocava os motoristas em contato com possíveis clientes ${ }^{39}$.

\footnotetext{
${ }^{37}$ CAVALCANTE, Sávio; FILGUEIRAS, Vitor. O trabalho no século XXI e o novo adeus a classe trabalhadora. Revista princípios, no 159, jul.-out., 2020.

${ }^{38}$ ABÍLIO, Ludmila. Uberização do trabalho: subsunção real da viração. Passa Palavra: Campinas, 2017. Disponível em: https://passapalavra.info/2017/02/110685/. Acesso em: 02 set. 2020.

39 JONES, Rubert. Uber driver earned less than minimum wage, tribunal told. The Guardian, Londres, 20 de jul. de 2016. Disponível em: https://www.theguardian.com/business/2016/jul/20/uber-driver-employmenttribunal-minimum-wage. Acesso em: 13 set. 2020.
} 
Assim, os aplicativos de entrega, intencionalmente, ocultam do seu modelo de negócios, a subordinação estrutural e a forma de assalariamento estabelecida entre o entregador e o aplicativo. O trabalhador é considerado usuário da plataforma, supostamente não possuindo chefe, gerente ou patrão, tendo "liberdade" para ligar ou não o aplicativo, aceitar ou negar entregas, estando sob seu poder de decisão a flexibilidade do seu horário de trabalho e a fixação da remuneração proporcionalmente à produtividade. Esse trabalhadorperfil é entendido e visto como "empreendedor", que utilizada da plataforma para organizar seu trabalho, criar conexões e ter acesso a clientes que possam usufruir dos seus serviços.

Importante destacar que essa ideia de "empreendedor" e "homem-empresa" vendida e propagada pelas plataformas, em verdade, se configura como uma nova forma de subsunção do trabalho ao capital no contexto da racionalidade financeira-tecnológica-neoliberal, confirmando-se como mera retórica para justificar e legitimar a exploração dos trabalhadores, que tiveram a sua condição de sujeito de direitos trabalhistas retirada ${ }^{40}$.

Então, a organização estrutural das empresas-aplicativo de entrega não se funda em um modelo de negócios tradicional - em que há a necessidade de uma subordinação direta entre um patrão e empregados - mas sim em um novo arranjo no qual os comandos e penalidades partem de pessoas utilizando o fetiche algorítmico, para intermediar os comandos de subordinação. Ao invés de criar um sistema de cargos e de chefia para controlar os trabalhadores, é utilizada a tecnologia para a realização do mapeamento do trabalho de milhares de pessoas, ao mesmo tempo, cruzando os dados de demanda, tempo de entrega e avaliação dos consumidores ${ }^{41}$.

As plataformas como a Uber e os demais aplicativos de entrega que seguem a mesma lógica estabelecem unilateralmente as regras, critérios de avaliação, mecanismos de vigilância sobre a força de trabalho, ao mesmo tempo em que se eximem de quaisquer responsabilidades e obrigações que poderiam de alguma forma configurar um vínculo

\footnotetext{
${ }^{40}$ ABÍLIO, Ludmila Costhek; SABINO, André Monici. Uberização - o Empreendedorismo como novo nome para a exploração. In: Revista Jurídica Trabalho e Desenvolvimento Humano, Campinas, v. 2, n. 2, dez. 2019. Disponível em: http://www.revistatdh.org/index.php/Revista-TDH/article/view/53. Acesso em: 16 fev. 2020.

${ }^{41}$ MATSU, Carlos. Uberização do trabalho e os limites de se trabalhar para um algoritmo. 2019. Disponível em: https://computerworld.com.br/2019/07/26/uberizacao-do-trabalho-e-os-limites-de-se-trabalhar-para-umalgoritmo/. Acesso em: 15 fev. 2020; NABUCO, Joaquim. O abolicionismo. São Paulo: Publifolha, 2000. (Grandes nomes do pensamento brasileiro da Folha de São Paulo).
} 
empregatício clássico. Articula-se aqui consumo, avaliação, coleta de dados e vigilância permanente, onde algoritmos e as tecnologias de aprendizado de máquina assumem a função de dispositivos panópticos de novo tipo.

Abílio $^{42}$ sinaliza que o controle sobre o trabalho é transferido para a multidão de consumidores, que avaliam os profissionais a cada serviço demandado. A certificação sobre o trabalho vem agora através da esfera do consumo, convertendo a multidão numa espécie de gerente coletivo que fiscaliza ininterruptamente os trabalhadores. Assim, os trabalhadores das plataformas de entrega sentem-se permanentemente vigiados e avaliados. É criada a ideia de que uma "mão invisível" coordena toda a atividade, de fato, não existe um chefe direto que ordene as entregas e defina o horário de trabalho dos entregadores ${ }^{43}$. Contudo, não existe essa "mão invisível" e sim uma empresa, com uma grande equipe de recursos humanos controlando o algoritmo do aplicativo para intermediar as ordens para os empregados, o trabalhador uberizado.

Tanto a organização quanto a forma de reprodução do trabalho dos entregadores de aplicativo apresentadas na atualidade - em termos práticos - não se diferem do assalariamento, sendo apenas reelaboradas em novas estratégias de gestão, viabilizadas pelo algoritmo e tecnologia que escamoteiam os pressupostos para a relação de trabalho, a qual não se difere do trabalho assalariado ${ }^{44}$. A programação da inteligência humana é utilizada para organizar os dados - elementos relevantes da indústria 4.0 - para reger o fluxo de entregas, logística de pagamentos, gorjetas, avaliações e penalidades de forma que parece tudo automático e fruto da tecnologia, do algoritmo. Essa forma de subordinação e controle que alia tecnologia e a centralidade do trabalho humano tem se mostrado eficaz para o capital, pois maximiza e amplia a produtividade, principalmente na incorporação dos

\footnotetext{
${ }^{42}$ ABÍLIO, Ludmila. Uberização do trabalho: subsunção real da viração. Passa Palavra: Campinas, 2017. Disponível em: https://passapalavra.info/2017/02/110685/. Acesso em: 02 set. de 2020.

${ }^{43}$ MATSU, Carlos. Uberização do trabalho e os limites de se trabalhar para um algoritmo. 2019. Disponível em: https://computerworld.com.br/2019/07/26/uberizacao-do-trabalho-e-os-limites-de-se-trabalhar-para-umalgoritmo/. Acesso em: 15 de fev. 2020; NABUCO, Joaquim. O abolicionismo. São Paulo: Publifolha, 2000. (Grandes nomes do pensamento brasileiro da Folha de São Paulo).

${ }^{44}$ CAVALCANTE, Sávio; FILGUEIRAS, Vitor. O trabalho no século XXI e o novo adeus a classe trabalhadora. Revista princípios, no 159, jul.-out., 2020.
} 
procedimentos - unilateralmente estabelecidos pelas empresas-plataforma - para o trabalhador.

Os impactos deste processo de rompimento com o padrão de proteção social historicamente construído e positivado na Consolidação das Leis do Trabalho e na Constituição Federal, fragiliza a proteção social, pois, retira direitos já postos. Ou seja, o ponto nevrálgico da questão atinente a essa nova massa de intermitentes digitais ${ }^{45}$ é a existência de um modelo de negócios que retira dos trabalhadores a sua qualidade de sujeito de direitos, precarizando os trabalhadores e reduzindo a dignidade do trabalhador. Este grupo se encontra no que Cavalcante e Filgueiras ${ }^{46}$ chamam de zona cinzenta, onde não há a efetiva autonomia do empreendedor, tampouco a proteção mínima das leis trabalhistas outorgadas ao trabalhador.

Vive-se um cenário de verdadeira precarização do mundo do trabalho caracterizado não mais pelo emprego em condições precárias, como se observava anteriormente, mas sim, pela tentativa de burlar a existência da própria relação de emprego, negando ao trabalhador a condição de empregado através de contratos de parceria, fomento ao empreendedorismo, falso associativismo, entre outros, o que culminou com o atual cenário de insurgência dos entregadores de aplicativos por meio de movimentos coletivamente organizados. Dessa forma, pensar medidas - jurídicas e coletivas - que vencem a fragmentariedade do trabalho e alcance o pertencimento da classe trabalhadora enquanto classe social constitui um grande desafio contra o avanço das medidas neoliberais precarizantes.

A Constituição fixa um patamar civilizatório mínimo para contratação e gestão da mão de obra no Brasil, ao elencar um rol de direitos trabalhistas e previdenciários visando a melhoria da condição da classe trabalhadora. Ademais, o entendimento firmado no inciso IV, do artigo 1 o foi novamente reafirmado no artigo 170 do mesmo dispositivo legal, ao defender que a construção de uma ordem econômica deve ser fundada na valorização do trabalho humano e na livre iniciativa, assegurando a todos, uma existência digna, a justiça social, a função social da propriedade, a redução das desigualdades regionais e sociais e o pleno

\footnotetext{
${ }^{45}$ ANTUNES, Ricardo. O privilégio da servidão. São Paulo: Boitempo, 2018.

${ }^{46}$ CAVALCANTE, Sávio; FILGUEIRAS, Vitor. O trabalho no século XXI e o novo adeus a classe trabalhadora. Revista princípios, no 159, jul.-out., 2020.
} 
emprego ${ }^{47}$. Em outros termos, essa forma de contratação rompe, de forma ilegalmente, com o pacto de proteção ao trabalho digno feito pelo constituinte.

Considerando as condições de trabalho dos entregadores de aplicativo narradas nas linhas anteriores, nota-se que, apesar de os aplicativos de entrega proporcionarem a geração de renda para parcela da população, estes não promovem o trabalho digno ${ }^{48}$, uma vez que sobre estas relações, tal como conformadas pelos aplicativos de entregas, não incidem diversas regras fundamentais para a garantia do patamar civilizatório mínimo, tais como a de limitação razoável da jornada e a promoção da segurança e higiene do trabalho.

Essa forma de contratação em que o obreiro é um empreendedor de si mesmo rebaixa a proteção mínima constitucionalmente assegurada aos trabalhadores. Contudo, mesmo que essas empresas defendam que esses trabalhadores não são empregados, o princípio fundamental da primazia da realidade ${ }^{49}$ pode ser invocado e a realidade fática mostrará o contrário.

3. \#BrequedosApps: a organização coletiva dos entregadores de aplicativos contra a precarização do trabalho

A luta dos entregadores de aplicativo pela instituição de direitos não deixa esquecer que a história humana ocidental é marcada por grandes insurgências populares, sobretudo, greves reivindicatórias por melhores condições de trabalho e por uma remuneração minimamente digna. Esses trabalhadores, sobretudo, com a emergência da pandemia sanitária da Covid-19, descobriram, bem como mostraram para a sociedade, ser uma categoria essencial no abastecimento da cidade, fator que impulsionou os movimentos paredistas de julho de 2020, que ficaram nacionalmente conhecidos como o \#BrequedosApps.

\footnotetext{
${ }^{47}$ DELGADO, Gabriela Neves. Direito Fundamental ao Trabalho Digno. E-book: LTr, 2012.

$48 \mathrm{O}$ direito fundamental ao trabalho digno deve ser uma regra prevalecente no âmbito do Direito do Trabalho brasileiro, sendo este, por sua vez, assegurado por meio de um feixe de direitos trabalhistas que garantem o patamar civilizatório mínimo (DELGADO, Gabriela Neves. Direito Fundamental ao Trabalho Digno. E-book: LTr, 2012).

${ }^{49}$ Conforme Pinto, este princípio defende que havendo divergência entre as condições ajustadas na relação empregatícia, sempre a realidade dos fatos prevalecerá (PINTO, José Augusto Rodrigues. Curso de direito individual do trabalho: noções fundamentais de direito do trabalho, sujeitos e institutos do direito individual. 5 ed. São Paulo. LTr. 2003).
} 
O \#BrequedosApps colocou em evidência algumas tendências estruturais do mercado de trabalho nacional, como a alta rotatividade, altas jornadas, alta intensidade dos processos de trabalho, baixos níveis salariais, baixa qualificação profissional e baixa cobertura social. É como bem diz o Rap dos Informais: "Agora dão duas opções para quem é pobre, morrer na rua de corona ou em casa de fome. Entre morrer em casa e morrer na rua eu prefiro nenhuma das duas" 50 .

Esse foi um marco histórico na organização coletiva do trabalho precário, representando uma esperança, assim como as greves do $A B C$ paulista indicaram um caminho para a constituição do novo sindicalismo e uma frente contra a crise da ditadura militar. Esse movimento grevista mostrou que os trabalhadores precários não são inorganizáveis, ao contrário. O \#BrequedosApps revelou para a sociedade a corrosão acelerada das condições de trabalho provocada pela gestão neoliberal e como esse novo modelo utiliza o fetiche da tecnologia para burlar direitos sociais em favor do capital ${ }^{51}$.

Nessa nova morfologia do trabalho no século XXI, a forma de ser da classe trabalhadora foi alterada substancialmente. Nessa nova tendência, acompanhamos o surgimento de novas categorias, um proletariado ${ }^{52}$ de novo tipo, ou, a "classe que vive do trabalho" como prefere Antunes $^{53}$. São os novos proletários de serviços, onde as trabalhadoras de telemarketing e call center, os motofretistas que percorrem ruas e avenidas, os desenvolvedores de software, os correspondentes bancários, os jovens trabalhadores do fast-food são exemplos característicos. "São partes constitutivas das forças sociais do trabalho que Ursula Huws sugestivamente denominou como cibertariado - o novo proletariado da era da cibernética que vivencia um trabalho (quase) virtual em um mundo (muito) real" 54 .

\footnotetext{
50 BRAGA, Ruy. \#BrequeDosApps: enfrentando o uberismo. Disponível em: https://blogdaboitempo.com.br/2020/07/25/brequedosapps-enfrentando-o-uberismo/. Acesso em: 19 set. 2020.

${ }^{51}$ GALVÃO, Andréia. A greve e as perspectivas do movimento entregadores. A Terra é Redonda, São Paulo, 14 de jul. de 2020. Disponível em: https://www.eco.unicamp.br/remir/index.php/sindicalismo/189-a-greve-e-asperspectivas-do-movimento-entregadores. Acesso em: 03 dez. 2020.

52 MARX, Karl; ENGELS, Friedrich. Manifesto do Partido Comunista. Tradução Antônio Carlos Braga. São Paulo: Escala, 2009, p. 53.

${ }^{53}$ ANTUNES, Ricardo. Riqueza e miséria do trabalho no Brasil IV: trabalho digital, autogestão e expropriação da vida: o mosaico da exploração. Org. Ricardo Antunes. 1 ed. São Paulo: Boitempo, 2019, p. 16.

54 ANTUNES, Ricardo; BRAGA, Ruy. (Orgs.). Infoproletários: degradação real do trabalho virtual. São Paulo: Boitempo, 2009.
} 
Dentro dessa realidade contemporânea, a Rede de Estudos e Monitoramento da Reforma Trabalhista (REMIR TRABALHO) ${ }^{55}$ realizou uma pesquisa entre os dias 13 e 20 de abril, ouvindo 252 pessoas por meio de um questionário online. A pesquisa teve por objetivo investigar as condições de trabalho dos entregadores por aplicativo no período da pandemia. Os dados mostram que $60,3 \%$ dos entrevistados relataram uma queda na remuneração, comparando em relação ao o período anterior à pandemia. Outros $27,6 \%$ disseram que os ganhos se mantiveram e apenas 10,3\% disseram que estão ganhando mais dinheiro durante a quarentena. Revelam ainda que, antes da pandemia $48,7 \%$, dos entregadores recebiam, no máximo, $\mathrm{R} \$ 520,00$ semanais. Durante a pandemia, esse número representou $72,8 \%$ dos entrevistados. $62,3 \%$ dos trabalhadores revelaram não ter recebido nenhum apoio das empresas para as medidas de prevenção do contágio, o que tem gerado custos adicionais ao trabalho.

Vitor Filgueiras e Ricardo Antunes apresentam dados que oferecem um raio-X preciso do perfil dos trabalhadores em plataformas digitais. Categoria predominantemente masculina (88\%), com a faixa etária entre 26 e 45 anos (69\%); escolaridade oscilando entre o ensino médio completo e superior completo (90\%); pouco tempo de trabalho com o aplicativo (89\% até dois anos); jornada diária de trabalho entre 6 e mais de 8 horas (77\%); dirigindo de 5 a 7 dias por semana (73\%); remuneração bruta inferior a $R \$ 2.000,00$ (90\%) por semana, tendo no aplicativo de transporte sua fonte única de remuneração (57\%).

De acordo com o levantamento realizado pelo Projeto Caminhos do Trabalho, do Núcleo de Estudos Conjunturais (NEC), abrangendo o universo de 103 entregadores, espalhados nas cinco regiões do país, especificamente em 38 cidades de 19 unidades da Federação: $76,7 \%$ dos respondentes a atividade de entrega por aplicativo é sua principal ocupação e $70 \%$ indicou não possuir outra ocupação; $89,3 \%$ do entrevistados laboram no regime de "nuvem", ou seja, sem jornada de trabalho predefinida e 7,8\% são operadores de logística, tem horários e folgas previamente definidas; a jornada média de trabalho desses

\footnotetext{
55 REMIR TRABALHO. Ministério Público do Trabalho produz a série "Por trás do Aplicativo" que denuncia as condições de trabalho dos trabalhadores por aplicativo no Brasil. Disponível em: https://www.eco.unicamp.br/remir/index.php/condicoes-de-trabalho/178-ministerio-publico-do-trabalhoproduz-a-serie-por-tras-do-aplicativo-que-denuncia-as-condicoes-de-trabalho-dos-trabalhadores-poraplicativo-no-brasil. Acesso em: 31 set. de 2020.
} 
Revista Jurídica Trabalho e Desenvolvimento Humano

Procuradoria Regional do Trabalho da 15a Região

entregadores é de 9 horas e 14 minutos diários (68,5\% trabalham 9 ou mais horas por dia), sendo que laboram cerca de 5,9 dias na semana (70,5\% trabalham 6 ou 7 dias por semana), o que equivale a cerca de 55,2 horas semanais ${ }^{56}$.

Ainda, importa trazer para análise que os trabalhadores informaram que houve uma queda de:

[...] $18,7 \%$ em seus rendimentos líquidos (descontados gastos como combustível, manutenção de veículos, internet, etc.) durante a pandemia. Considerando o rendimento líquido para um mês de trabalho, $44 \%$ dos entregadores conseguem menos do que um salário mínimo, e $85 \%$ menos do que 2 salários mínimos. Como suas jornadas são muito extensas e o descanso semanal muitas vezes não ocorre, o pagamento recebido por hora é mais adequado para calcular a magnitude dos seus ganhos. Nesses termos, $51,7 \%$ recebem, proporcionalmente por hora, menos do que 1 salário mínimo. Além das longas jornadas e baixos rendimentos, $82,2 \%$ dos entrevistados conhecem alguém que já foi bloqueado (o que significa uma suspensão temporária do trabalho), e 38,8\% sofreram diretamente essa punição, dos quais $43,7 \%$ não conseguiu sequer saber o motivo do bloqueio. Ademais, $33 \%$ dos entregadores informaram terem sofrido acidente no trabalho atual. Somados aos que conhecem alguém que sofreu acidente, são $70 \%$ dos entrevistados. Dos acidentados, $72,1 \%$ criticaram a falta de apoio da empresa ou foram bloqueados após o infortúnio ${ }^{57}$.

Em suma, são jovens, não detentores dos meios de produção, que necessitam vender sua força de trabalho para prover o sustento material pessoal e familiar, muitas vezes na informalidade total ou na condição de empregados precários. A configuração dessa classe trabalhadora é diversa e ao longo do tempo novas categorias vão surgindo e outras desaparecendo, mas o que permanece é a centralidade do trabalho no mundo capitalista, independentemente da configuração.

Importa salientar que as redes sociais tem sido uma importante ferramenta para essa integração entre esses trabalhadores, visto que a dinâmica de organização do trabalho cotidiana geralmente não propicia uma interação física satisfatória entre esses trabalhadores.

\footnotetext{
${ }^{56}$ FILGUEIRAS, Vitor et al. Projeto Caminhos do Trabalho: tendências, dinâmicas e interfaces, do local ao global. Universidade Federal da Bahia, Salvador, 2020. Disponível em: http://abet-trabalho.org.br/wpcontent/uploads/2020/08/Relato\%CC\%81rio-de-Levantamento-sobre-Entregadores-por-Aplicativos-noBrasil.pdf. Acesso em: 03 dez.2020.

57 FILGUEIRAS, Vitor et al. Projeto Caminhos do Trabalho: tendências, dinâmicas e interfaces, do local ao global. Universidade Federal da Bahia, Salvador, 2020. Disponível em: http://abet-trabalho.org.br/wpcontent/uploads/2020/08/Relato\%CC\%81rio-de-Levantamento-sobre-Entregadores-por-Aplicativos-noBrasil.pdf. Acesso em: 03 dez. 2020.
} 
Dessa forma, demonstraram criatividade em seus processos de luta ao utilizarem as redes sociais (WhatsApp, Telegram, Facebook, Instagram e Twitter) para ampliar a capacidade de mobilização da categoria e incidir junto à opinião pública, divulgando suas pautas e bandeiras de reivindicação. Essa organização nas redes sociais proporcionou o desenvolvimento de instituições formais de luta contra a precarização do trabalho, seja por meio de associações, por meio de sindicatos (geralmente organizados por cidades), seja pela integração internacional desses trabalhadores (como a Rede Transnacional de Trabalhadores - RTT) que reúne entidades coletivas de vários países).

Contudo, essa incipiente categoria, bem como os movimentos grevistas de julho não são ideologicamente homogêneos. Conforme demonstra Galvão58, a pauta dos manifestantes compreende diversas demandas e posicionamentos. E como todo processo de organização coletiva, isso abre espaço para a formação de grupos com posições e interesses distintos. $\mathrm{Na}$ disputa em torno do tamanho da proteção estatal, então, existe uma divisão no movimento dos entregadores, sobretudo, entre sindicatos e associações, por exemplo, uma nova greve foi marcada para o dia 25 de julho, contudo, o Sindimoto SP marcou a greve para o dia 14.

Em relação a heterogeneidade física, não se pode afirmar o mesmo. Conforme o Relatório de Pesquisa, já mencionado: 95\% dos entregadores são homens, 89,2\% jovens (entre 18 até 30 anos) e $59,2 \%$ negros (soma dos $19,4 \%$ pretos com os $39,8 \%$ pardos) ${ }^{59}$. Portanto, existe uma convergência no perfil de cor, sexo e idade presente nesse proletariado de plataforma.

Esse movimento teve um saldo positivo. Galvão destaca: a) deu publicidade ao debate político-ideológico a respeito das falácias neoliberais de que os trabalhadores de plataforma são empreendedores e que possuem total autonomia; b) bem como "recolocou o trabalho no centro do tabuleiro e jogando luz sobre a necessidade de mudanças, urgentes e necessárias,

\footnotetext{
${ }^{58}$ GALVÃO, Andréia. A greve e as perspectivas do movimento entregadores. A Terra é Redonda, São Paulo, 14 de jul. de 2020. Disponível em: https://www.eco.unicamp.br/remir/index.php/sindicalismo/189-a-greve-e-asperspectivas-do-movimento-entregadores. Acesso em: 03 dez. 2020.

${ }^{99}$ FILGUEIRAS, Vitor et al. Projeto Caminhos do Trabalho: tendências, dinâmicas e interfaces, do local ao global. Universidade Federal da Bahia, Salvador, 2020. Disponível em: http://abet-trabalho.org.br/wpcontent/uploads/2020/08/Relato\%CC\%81rio-de-Levantamento-sobre-Entregadores-por-Aplicativos-no-

Brasil.pdf. Acesso em: 03 dez. 2020.
}

CARVALHO, Felipe S. E. de; PEREIRA, Súllivan dos Santos; SOBRINHO, Gabriela Sepúlveda. \#BrequeDosApps e a organização coletiva dos entregadores por aplicativo no Brasil. Revista Jurídica Trabalho e Desenvolvimento Humano, Campinas, v. 3, p. 1-29, 2020. 
nas condições de trabalho de uma categoria descoberta como essencial" ${ }^{60}$; c) provocou um posicionamento público das empresas; d) motivou a criação de empresas autogeridas pelos próprios trabalhadores (ex: cooperativas, associações etc.); e) mostrou que os trabalhadores precários não são inorganizáveis; e f) fomentou o protocolo de Projetos de Lei visando a regulação do trabalho desses cidadãos(as).

Braga $^{61}$ destaca que o sucesso do \#BrequedosApps pode ser medido pela formação de um novo sujeito coletivo no debate público. Se antes eram trabalhadores precários invisíveis no grande fluxo de capitais, conseguiram por meio da ação coletiva, chamar a atenção da imprensa, da sociedade em geral, forçando o pronunciamento das empresas e adoção de medidas para conter a exposição negativa de suas marcas comerciais. Avaliando o futuro do movimento, talvez o desafio resida no plano da articulação e interlocução entre o sindicalismo já constituído e as novas formas de mobilização, uma vez que existem associações e sindicatos que representam parte da categoria. Outro desafio que se impõe é a busca pela incorporação de novos trabalhadores nos processos de luta, além de potencializar o apoio de outros setores profissionais e dos próprios consumidores desses serviços.

\section{CONSIDERAÇÕES FINAIS}

As categorias de trabalhadores não nascem de teses acadêmicas, nascem da experiência empírica e material, da dinâmica econômica e social. Com os entregadores por aplicativo não foi diferente, com a plataformização das empresas de delivery, surge também a classe que trabalha para essas empresas, no caso, os entregadores por aplicativo e consequentemente 0 sentimento de pertencer a classe nascente e a necessidade de organização coletiva para defender seus direitos.

\footnotetext{
${ }^{60}$ GALVÃO, Andréia. A greve e as perspectivas do movimento entregadores. A Terra é Redonda, São Paulo, 14 de jul. de 2020. Disponível em: https://www.eco.unicamp.br/remir/index.php/sindicalismo/189-a-greve-e-asperspectivas-do-movimento-entregadores. Acesso em: 03 dez. 2020.

${ }^{61}$ BRAGA, Ruy; SANTANA, Marco Aurélio. \#BrequedosApps: enfrentando o uberismo. Boitempo, 25 de jul. de 2020. Disponível em: https://blogdaboitempo.com.br/2020/07/25/brequedosapps-enfrentando-o-uberismo/. Acesso em: 22 set. 2020.
} 
Como já vimos, os trabalhadores das plataformas digitais são inseridos, do ponto de vista formal-contratual, na posição jurídica de parceiros autônomos. São tidos pela empresa como livres para escolher o horário de prestação dos serviços; contudo, por ganharem tão pouco, são impelidos sempre a trabalhar o máximo possível, num forma oculta de radicalização do trabalho remunerado por peça.

Essa forma de contratar a força de laboral utiliza como estratégia a flexibilização do trabalho (uma forma de transferir os riscos do empreendimento para os empregados), bem como vai contra todos os direitos trabalhistas historicamente conquistados, visto que rebaixa a proteção mínima assegurada aos hipossuficiente, assim como ignora os preceitos constitucionais que asseguram um trabalho digno.

Todos os dados trazidos ao longo deste texto são importantes para demonstrar, empiricamente, que, quando se afirma que os entregadores de aplicativo são precarizados em relação ao trabalhador contrato por tempo indeterminado e regido integralmente pela Consolidação das Leis do Trabalho, quer-se dizer que esses obreiros não têm sequer as garantias constitucionais mínimas asseguradas, por isso, todos os processos reivindicatórios ocorridos ao longo deste ano.

Essa forma de contratação da mão de obra beneficia apenas para um sujeito da relação contratual, o empregador. Inclusive, a ausência de regras trabalhistas que resguardem a relação entre os entregadores e os aplicativos já vem causando diversos acidentes de trabalho, seja pelo excesso de horas de trabalho, ausência de equipamentos de proteção ou estresse gerado pelo excesso de entregas, questões que ainda foram acentuadas pela pandemia do vírus COVID-19.

É uma sociedade que vive do trabalho e para o trabalho, pois fora do trabalho não é possível viver, ignorando totalmente o acordo liberal feito no século XIX de oito horas de sono, oito horas de trabalho e oito horas de lazer. Ainda, importa mencionar que em alguns países, a exemplo da França, a jornada padrão prevalecente no welfare state são de seis horas de trabalho. Por certo que essa política pós-estado de bem estar social está ameaçada, também nesse país, e que essa não é a realidade dos subtrabalhadores, a exemplo dos refugiados e imigrantes. 
Em um primeiro momento, a greve dos entregadores expressa a luta de uma categoria pela ampliação da proteção social via instituição de direitos e garantias trabalhistas. Todavia, o exercício laboral em condições degradantes e sem cobertura social aproxima a luta dos entregadores de aplicativo à realidade de outras categorias, importantes, igualmente numerosas e historicamente marginalizadas no Brasil. Assim, como em outras oportunidades, o capital elabora formas de retirar "custos trabalhistas" e lucrar a partir da força do proletário, como ocorreu em com "ganhadores", "trabalhadores avulsos", "pejotas", "trabalhadores intermitentes" e "empreendedores", gerando tensões entre capital e trabalho.

$\mathrm{Na}$ atual quadratura histórica, vive-se mais um destes ciclos de precarização, o qual encontrou e encontra respostas no campo da organização coletiva e direito do trabalho. Esse fato nos coloca o desafio de pensar o direito do trabalho como resultado político e jurídico de uma experiência fordista tardia (representada no projeto varguista), limitada a uma parcela restrita da força de trabalho nacional, cujas promessas de proteção esbarraram nas estruturas coloniais que sustentaram, por quase quatro séculos, as relações e instituições do trabalho a partir da desigualdade e subjugo racial.

Apesar de existirem diversas formas de precarização do trabalho, a vivida na atualidade pelos entregadores de aplicativo preocupa não apenas pela aceleração do processo viabilizado pela tecnologia e pelas empresas-plataforma, mas também pela impossibilidade de proteger o trabalhador por meio do manto trabalhista já existente. Isto é, os moldes existentes e características para o reconhecimento da relação de emprego (trabalhador assalariado) não se coadunam - por completo - com o atual cenário, se quedando esta classe em uma zona indefinida. Neste sentido, indaga-se: seria a construção de uma nova regulação a saída? Como enquadrar trabalhadores de aplicativo em relações típicas de emprego?

O direito a um trabalho protegido e devidamente regulamentado é o mínimo que pode assegurar aos trabalhadores enquanto sujeitos de direito, garantindo a dignidade do obreiro. Assim, considerando o metamorfoseamento das relações sociais de produção, novas dimensões/formas de subordinação devem ser (re)pensadas e a partir desta nova estruturação pensar a possibilidade de proteção deste trabalhador - que, apesar de se reconhecer enquanto classe - ainda se encontra ameaçado pela forma de produção capitalista, 
Revista Jurídica Trabalho e Desenvolvimento Humano

Procuradoria Regional do Trabalho da 15a Região

tendo os seus direitos trabalhistas retirados em razão da estruturação de modelo de negócios das "empresas-plataforma".

\section{REFERÊNCIAS}

ABÍLIO, Ludmila. Uberização do trabalho: subsunção real da viração. Passa Palavra: Campinas, 2017. Disponível em: https://passapalavra.info/2017/02/110685/. Acesso em: 02 set. 2020.

ABÍLIO, Ludmila. Uberização do trabalho: Uberização: do empreendedorismo para o autogerenciamento subordinado. Revista Psicoperspectivas: Individuo y sociedad. Vol. 18, n. 3, p.1-11, 2019.

ABÍLIO, Ludmila Costhek; SABINO, André Monici. Uberização - o Empreendedorismo como novo nome para a exploração. In: Revista Jurídica Trabalho e Desenvolvimento Humano, Campinas, v. 2, n. 2, dez. 2019. Disponível em:

http://www.revistatdh.org/index.php/Revista-TDH/article/view/53. Acesso em: 16 fev. 2020.

ALVES, Raissa Roussenq. Entre o silêncio e a negação: trabalho escravo contemporâneo sob a ótica da população negra. Belo Horizonte: Letramento, 2019.

ANTUNES, Ricardo. Qual é o Futuro do Trabalho na era digital?. Revista Laborare, ano III, no 4, jan-jun/2020.

ANTUNES, Ricardo. $O$ privilégio da servidão. São Paulo: Boitempo, 2018.

ANTUNES, Ricardo. Riqueza e miséria do trabalho no Brasil IV: trabalho digital, autogestão e expropriação da vida: o mosaico da exploração. Org. Ricardo Antunes. 1 ed. São Paulo: Boitempo, 2019.

ANTUNES, Ricardo; BRAGA, Ruy. (Orgs.). Infoproletários: degradação real do trabalho virtual. São Paulo: Boitempo, 2009.

ANTUNES, Ricardo; FILGUEIRAS, Vitor. Plataformas, digitais, uberização do trabalho e regulação no capitalismo contemporâneo. Bazilian Journal of Communication, PPGCOM-UFF. v. 39, n. 1, 2020.

BOURDIEU, Pierre. Contrafogos: táticas para enfrentar a invasão neoliberal. Tradução Lucy Magalhães. Rio de Janeiro: Jorge Zahar, 1998.

BRAGA, Ruy; SANTANA, Marco Aurélio. \#BrequedosApps: enfrentando o uberismo.

Boitempo, 25 de jul. de 2020. Disponível em: 
https://blogdaboitempo.com.br/2020/07/25/brequedosapps-enfrentando-o-uberismo/. Acesso em: 22 set. de 2020.

BRASIL. Paim diz que greve atingiu 40 milhões de trabalhadores e foi a maior da história do país. In: Agência Senado. Brasília: Senado Federal, 2017.

BREQUE dos Apps: nossas vidas valem mais do que o lucro deles. Esquerda Diário, São Paulo, 02 de jul. de 2020. Disponível em: https://www.esquerdadiario.com.br/Breque-dosApps-nossas-vidas-valem-mais-que-o-lucro-deles. Acesso em: 22 set. de 2020.

BRIDI, Maria Aparecida; LIMA, Jacob Carlos. Trabalho digital e emprego: a reforma trabalhista e o aprofundamento da precariedade. Caderno CRH [online]. 2019, vol. 32, n. 86 [cited 2020-09-24], pp.325-342. Disponível em:

http://www.scielo.br/scielo.php?script=sci arttext\&pid=\$010349792019000200325\&lng=en \&nrm=iso. Acesso: em 18 set. 2020.

CAMPOS, Cauê. Conflitos trabalhistas nas obras do PAC: o caso das Usinas Hidrelétricas de Jirau, Santo Antônio e Belo Monte. Campinas, SP: Dissertação, 2016.

CAVALCANTE, Sávio; FILGUEIRAS, Vitor. O trabalho no século XXI e o novo adeus a classe trabalhadora. Revista princípios, no 159, jul.-out., 2020.

CHALHOUB, Sidney. Cidade febril: cortiços e epidemias na Corte imperial. São Paulo: Companhia das Letras, 1996.

CHALHOUB, Sidney. Sujeitos no imaginário acadêmico: escravos e trabalhadores na historiografia brasileira desde os anos 1980. Cad. Ael, v. 14, n. 26, 2009.

CHALHOUB, Sidney. Trabalho, lar e botequim: o cotidiano dos trabalhadores no Rio de Janeiro da Belle Époque. São Paulo: Brasiliense, 1986.

DARDOT, Pierre; LAVAL, Christian. A nova razão do mundo: ensaio sobre a sociedade neoliberal. São Paulo: Boitempo, 2016.

DELGADO, Gabriela Neves. Direito Fundamental ao Trabalho Digno. E-book: LTr, 2012.

DRUCK, Maria da Graça. Trabalho, precarização e resistências: novos e velhos desafios? Cadernos CRH, Salvador, v. 24, p. 37-57, 2011.

GALVÃO, Andréia. A greve e as perspectivas do movimento entregadores. A Terra é Redonda, São Paulo, 14 de jul. de 2020. Disponível em: https://www.eco.unicamp.br/remir/index.php/sindicalismo/189-a-greve-e-as-perspectivasdo-movimento-entregadores. Acesso em: 03 dez. 2020. 
GRAVAS, Douglas. Aplicativos como Uber e iFood são fonte de renda de quase 4 milhões de autônomos. $O$ Estado de São Paulo, 2020. Disponível em:

https://www.ilocomotiva.com.br/single-post/2019/04/29/ESTAD\%C3\%830-Na-criseaplicativos-como-Uber-e-iFood-viram-maior-empregador-do-pa\%C3\%ADs. Acesso em: 24 set. 2020.

FERREIRA, António Casimiro. A sociedade da austeridade: poder, medo e direito do trabalho de exceção. In: Revista Crítica de Ciências Sociais. Online, 95, 2011.

FILGUEIRAS, Vitor et al. Projeto Caminhos do Trabalho: tendências, dinâmicas e interfaces, do local ao global. Universidade Federal da Bahia, Salvador, 2020. Disponível em: http://abettrabalho.org.br/wp-content/uploads/2020/08/Relato\%CC\%81rio-de-Levantamento-sobreEntregadores-por-Aplicativos-no-Brasil.pdf. Acesso em: 03 dez. 2020.

FONSECA, Lígia Ferreira. Luiz Gama por Luiz Gama: carta a Lúcio de Mendonça. Teresa revista de Literatura Brasileira. São Paulo, 2008, p. 300-321.

FREYRE, Gilberto. Sobrados e Mocambos. 3 ed. Rio de Janeiro: José Olympio, 1961.

JONES, Rubert. Uber driver earned less than minimum wage, tribunal told. The Guardian, Londres, 20 de jul. de 2016. Disponível em: https://www.theguardian.com/business/2016/jul/20/uber-driver-employment-tribunalminimum-wage. Acesso em: 13 set. 2020.

KOWARICK, Lúcio. Trabalho e vadiagem: A origem do trabalho livre no Brasil. 2 ed. Rio de Janeiro: Paz e Terra, 1994.

MATSU, Carlos. Uberização do trabalho e os limites de se trabalhar para um algoritmo. 2019. Disponível em: https://computerworld.com.br/2019/07/26/uberizacao-do-trabalho-e-oslimites-de-se-trabalhar-para-um-algoritmo/. Acesso em: 15 fev. 2020.

NABUCO, Joaquim. O Abolicionismo. São Paulo: Publifolha, 2000.

OLIVEIRA, Murilo Carvalho Sampaio. Formas de contratação do trabalhador na prestação de serviços sob plataformas. In: CARELLI, Rodrigo de Lacerda; CAVALCANTI, Tiago M.; FONSECA, Vanessa Patriota da. Futuro do Trabalho: os efeitos da revolução digital na sociedade. Brasília: ESMPU, 2020.

PACHUKANIS, Evguiéni Bronislávovitch. Teoria Geral do Direito e Marxismo. Trad. Paula Vaz de Almeida. São Paulo: Boitempo, 2017, p. 02.

PINTO, José Augusto Rodrigues. Curso de direito individual do trabalho: noções fundamentais de direito do trabalho, sujeitos e institutos do direito individual. 5 ed. São Paulo. LTr. 2003. 
PIRES, Thula Rafaela de Oliveira. Criminalização do Racismo entre política de reconhecimento e meio de legitimação do controle social dos não reconhecidos; orientadora: Gisele Cittadino. 2v. Tese (Doutorado em Direito) - Pontifícia Universidade Católica do Rio de Janeiro, Departamento de Direito, Rio de Janeiro, 2013.

QUEIROZ, Marcus. Constitucionalismo e Atlântico Negro. 2 ed. São Paulo: Lumen Juris, 2018.

REIS, João José. Ganhadores: a greve negra de 1857 na Bahia. São Paulo: Companhia das Letras, 2019.

REIS, João José. Rebelião escrava no Brasil: a história do levante dos malês em 1835. São Paulo: Companhia das Letras, 2003.

REMIR TRABALHO. Ministério Público do Trabalho produz a série "Por trás do Aplicativo" que denuncia as condições de trabalho dos trabalhadores por aplicativo no Brasil. Disponível em: https://www.eco.unicamp.br/remir/index.php/condicoes-de-trabalho/178-ministeriopublico-do-trabalho-produz-a-serie-por-tras-do-aplicativo-que-denuncia-as-condicoes-detrabalho-dos-trabalhadores-por-aplicativo-no-brasil. Acesso em: 31 set. 2020.

RIBEIRO, Gabriel Francisco. Greve não para apps, mas mostra força de entregadores, nova data é votada. UOL, São Paulo, 01 de jul. de 2020. Disponível em:

https://www.uol.com.br/tilt/noticias/redacao/2020/07/01/greve-nao-para-apps-mas-afetasistema-e-mostra-forca-de-entregadores.htm. Acesso em: 22 set. 2020.

SCHWAB, Klaus. The fourth industrial Revolution. World Economic Forum: Cologny/Geneva, Switzerland, 2016. 